\title{
Arundo donax L. reed: New perspectives for pulping and bleaching. 5. Ozone-based TCF bleaching of organosolv pulps
}

\author{
A.A. Shatalov *, H. Pereira \\ Centro de Estudos Florestais, Universidade Técnica de Lisboa, Instituto Superior de Agronomia, Tapada da Ajuda, 1349-017 Lisboa, Portugal
}

Received 22 September 2006; received in revised form 17 January 2007; accepted 21 January 2007

Available online 12 March 2007

\begin{abstract}
Three selected alkali-based organosolv pulps (alkali-sulfite-anthraquinone-methanol (ASAM), alkali-anthraquinone-methanol (organocell) and ethanol-soda) from agrofibre crop giant reed (Arundo donax L.) were bleached by an ozone-based TCF (totally chlorinefree) bleaching sequence $A Z E_{R} Q P$ (where $A$ is an acidic pulp pre-treatment, $Z$ is an ozone stage, $\left(E_{R}\right)$ is an alkaline extraction in the presence of reducing agent, $\mathrm{Q}$ is a pulp chelating, $\mathrm{P}$ is a hydrogen peroxide stage) without oxygen pre-bleaching, and compared with a conventional kraft pulp used as a reference. The different response on bleaching conditions within each bleaching stage was noted for all tested pulps. The pulp bleachability, in terms of brightness improvement or lignin removal per unit of applied chemicals, was found higher for the organocell pulp. The ASAM and ethanol-soda pulps showed the highest bleaching selectivity, expressed by viscosity loss per unit of lignin removed or brightness improved. The overall bleaching results of organosolv pulps were superior to kraft.
\end{abstract}

(C) 2007 Elsevier Ltd. All rights reserved.

Keywords: Giant reed; Arundo donax L.; Non-wood fibres; Ozone bleaching; Organosolv pulping

\section{Introduction}

Over the last decade, the increased market demand for totally chlorine-free (TCF) and low AOX (absorbable organic halogens) pulps caused a substantial renewed interest in non-chlorine oxidative bleaching chemicals such as oxygen, hydrogen peroxide and ozone. Ozone is the most powerful oxidation agent. Despite the considerable research to elucidate the bleaching capacity of ozone, completed already $30-40$ years ago, its commercial application became feasible only in the 1990s under the pressure of environmental issues in an effort to minimize discharges of chlorinated compounds in the bleaching plant effluents (Byrd et al., 1992; Liebergott et al., 1992a,b; Homer et al., 1996).

At present, an ozone bleaching stage is part of many ECF (elemental chlorine-free) and TCF commercial pulp bleaching sequences (Van Lierop et al., 1996). Ozone has proved to be a highly efficient and competitive bleaching chemical in

\footnotetext{
* Corresponding author. Tel.: +351 2136 34662; fax: +351 213645000 .

E-mail address: anatoly@isa.utl.pt (A.A. Shatalov).
}

terms of delignification ability, cost and ecological impact. The ozone bleaching stage was successfully applied to different types of conventional (sulfur-based) and unconventional (organosolv) pulps from a wide variety of woods and nonwood (agro-fibre) sources (Zimmermann et al., 1991; Puthson et al., 1997; Zhang et al., 1998; Saake et al., 1998; Bouchard et al., 2000; Bokstrom and Tuomi, 2001; Munro and Griffiths, 2001; Roncero et al., 2002; Roncero et al., 2003; Kishimoto et al., 2003; King and Van Heiningen, 2003).

Agro-fibres are of much current importance to papermaking as the only solution to make up for a shortage of wood fibres and to prevent thereby the fast global deforestation (Van Dam et al., 1994; Moor, 1996; Leminen et al., 1996). Giant reed (Arundo donax L.) is one of the wellknown fibre crops, which papermaking potential is now being intensively reconsidered. The high biomass productivity and ability to cultivation (Dalianis et al., 1994; Vecchiet et al., 1996), combined with appropriate chemical composition and good fibre properties (Perdue, 1958; Shatalov et al., 2001; Ververis et al., 2004), suggest the broad potential for giant reed application to pulp and 
paper production. The recent study on organic solventbased (organosolv) pulping of giant reed showed that competitive papermaking fibres (comparable with hardwoods) could be produced using this advanced pulping technology (Shatalov and Pereira, 2000, 2001, 2004). The organosolv fibres from $A$. donax were easily bleached to high brightness values by simple TCF three-stage hydrogen peroxide bleaching sequence, without any pulp pre-bleaching (Shatalov and Pereira, 2003, 2005).

In the present paper, the results on TCF bleachability of A. donax organosolv pulps by ozone-based bleaching sequence without oxygen pre-bleaching are reported. The bleaching results are compared with conventional kraft pulp, as a reference.

\section{Experimental}

\subsection{Raw material and pulping}

The whole stems of $A$. donax (including nodes and internodes) without leaves were used to prepare pulps for the bleaching experiments. The detailed chemical, anatomical and morphological characterization of the stem material of $A$. donax has been reported elsewhere (Shatalov et al., 2001). The ASAM (alkali-sulfite-anthraquinone-methanol), organocell (alkali-anthraquinone-methanol), ethanol-soda and kraft pulps were prepared by a $7 \mathrm{~L}$ laboratory-scale batch reactor with forced circulation of the cooking liquor using conditions described in our previous publications (Shatalov and Pereira, 2001, 2004). The principal properties of unbleached pulps are summarised in Table 1.

\subsection{Bleaching}

All the tested pulps were bleached under identical conditions with an $\mathrm{AZE} \mathrm{E}_{\mathrm{R}} \mathrm{QP}$ sequence (where $\mathrm{A}$ is an acidic pulp

Table 1

Properties of unbleached organosolv and kraft (ref.) pulps from $A$. donax

\begin{tabular}{|c|c|c|c|c|}
\hline & \multicolumn{4}{|c|}{ Pulping process } \\
\hline & Ethanol-soda & ASAM & Organocell & Kraft (ref.) \\
\hline $\begin{array}{l}\text { Yield ( } \% \text { on } \\
\text { oven-dry reed) }\end{array}$ & 46.8 & 46.5 & 45.7 & 43.2 \\
\hline $\begin{array}{l}\text { Lignin }(\% \text { on } \\
\text { oven-dry pulp) }\end{array}$ & 4.04 & 4.30 & 3.28 & 3.58 \\
\hline Klason & 2.45 & 3.05 & 2.17 & 2.57 \\
\hline Acid-soluble & 1.59 & 1.25 & 1.11 & 1.01 \\
\hline $\begin{array}{l}\text { Intrinsic viscosity } \\
\quad\left(\mathrm{ml} \mathrm{g}^{-1}\right)\end{array}$ & 1146 & 1142 & 967 & 1078 \\
\hline Brightness (\% ISO) & 40.5 & 38.9 & 31.8 & 30.2 \\
\hline Yellowness index & 39.2 & 32.4 & 41.1 & 39.3 \\
\hline $\begin{array}{l}\text { Burst index } \\
\qquad\left(\mathrm{kPa} \mathrm{m}^{2} \mathrm{~g}^{-1}\right)\end{array}$ & 1.42 & 1.31 & 1.08 & 0.96 \\
\hline $\begin{array}{l}\text { Tensile index } \\
\qquad\left(\mathrm{N} \mathrm{m} \mathrm{g} \mathrm{g}^{-1}\right)\end{array}$ & 21.51 & 19.20 & 19.12 & 15.56 \\
\hline $\begin{array}{l}\text { Tear index } \\
\qquad\left(\mathrm{mN} \mathrm{m}^{2} \mathrm{~g}^{-1}\right)\end{array}$ & 9.56 & 8.66 & 8.76 & 8.22 \\
\hline
\end{tabular}

Table 2

Bleaching conditions

\begin{tabular}{|c|c|c|c|c|c|}
\hline & \multicolumn{5}{|c|}{ Bleaching stage } \\
\hline & A & $\mathrm{Z}$ & $\mathrm{E}_{\mathrm{R}}$ & Q & $\mathrm{P}$ \\
\hline Pulp consistency $(\%)$ & 3 & 3 & 10 & 3 & 10 \\
\hline Temperature $\left({ }^{\circ} \mathrm{C}\right)$ & 20 & 20 & 60 & 50 & 90 \\
\hline Time (min) & 30 & 20 & 60 & 50 & 90 \\
\hline $\mathrm{O}_{3}(\%$ on oven-dry pulp) & - & 0.8 & - & - & - \\
\hline $\mathrm{H}_{2} \mathrm{O}_{2}(\%$ on oven-dry pulp) & - & - & - & - & 2.5 \\
\hline $\mathrm{NaOH}(\%$ on oven-dry pulp) & - & - & 1.0 & - & 1.5 \\
\hline EDTA ( $\%$ on oven-dry pulp) & - & - & - & 0.3 & - \\
\hline DTPA ( $\%$ on oven-dry pulp) & - & - & - & - & 0.2 \\
\hline $\mathrm{MgSO}_{4}(\% \text { on oven-dry pulp })^{\mathrm{a}}$ & - & - & - & - & 0.3 \\
\hline $\mathrm{NaBH}_{4}(\%$ on oven-dry pulp) & - & - & 0.1 & - & - \\
\hline $\mathrm{pH}^{\mathrm{b}}$ & 2.0 & 2.0 & - & 4.5 & - \\
\hline
\end{tabular}

pre-treatment, $\mathrm{Z}$ is an ozone stage, $\mathrm{E}_{\mathrm{R}}$ is an alkaline extraction in the presence of reducing agent, $\mathrm{Q}$ is a pulp chelating, $\mathrm{P}$ is a hydrogen peroxide stage), without oxygen pre-bleaching. The specific bleaching conditions of each stage are listed in Table 2.

To increase the selectivity of the ozone stage towards lignin, an acidic pulp treatment with a solution of sulfuric acid was done before ozonation. The reducing agent (sodium borohydride) was added to the alkaline extraction stage to convert the alkali-sensitive carbonyl groups of the carbohydrates to hydroxyl groups, thus preventing the alkaliinduced carbohydrate degradation (Lindholm, 1993). Before peroxide bleaching, the pulps were pre-treated with a chelating agent EDTA (ethylenediaminetetraacetic acid) to limit the effect of transition metals on alkaline decomposition of peroxide. The Epsom salt (magnesium sulfate) and DTPA (diethylenetriaminepentaacetic acid) were used as the additional chemicals during peroxide bleaching stage to minimize the radical degradation reactions of carbohydrates.

The acidic pulp treatment was carried out in open glass containers under room temperature and atmospheric pressure. The alkaline extraction stage as well as the pulp chelating and peroxide bleaching stage were performed in sealed plastic bags plunged into an agitated water bath with process temperature control. Ozone bleaching (low consistency) was performed in a 21 glass reactor (Fischer) equipped with a powerful stirrer and connected with a laboratory ozone generator (Fischer 502). After each bleaching stage, the pulps were thoroughly washed by deionized water and analysed for bleached yield, brightness, viscosity, residual lignin content and mechanical properties. The final bleached pulps were also analysed on mechanical properties after beating in a laboratory PFI mill.

\subsection{Pulp analysis}

Residual lignin content was determined as Klason and acid-soluble lignin according to T $222 \mathrm{om}-88$ and UM 250 TAPPI standards, respectively. Pulp viscosity was 
measured in cupri-ethylenediamine (CED) solution according to SCAN-CM 15:88 standard. Handsheet formation for physical and reflectance tests were performed according to TAPPI T 205 om-88 and TAPPI T 272 om-92 standards. Bursting, tensile and tearing strength of pulp handsheets were examined according to TAPPI T $220 \mathrm{om}-88$ standard. Pulp optical properties (ISO brightness and DIN $6167 \mathrm{C} / 2$ yellowness index) were measured by CM-3630 Spectrophotometer (Minolta).

All measurements were replicated to obtain reproducible data.

\section{Results and discussion}

With this paper we continue to examine the bleaching ability of organosolv pulps from giant reed by totally chlorine free (TCF) bleaching technologies. The simple three-stage hydrogen peroxide bleaching without oxygen pre-bleaching has been reported in our previous publication (Shatalov and Pereira, 2005). The final brightness of 76-78\% ISO was attained after complete peroxide bleaching. To consider the possibility of brightness improvement, the introduction of one ozone-stage within the short TCF sequence was studied.

\subsection{Properties of bleached pulps}

Three selected alkali-based organosolv giant reed pulps (ASAM, organocell and ethanol-soda) were bleached by $\mathrm{AZE}_{\mathrm{R}} \mathrm{QP}$ (actually ZEP) bleaching sequence without oxygen pre-bleaching, and compared with conventional kraft pulp. The bleaching results are shown in Table 3. It is evident that all organosolv pulps can be bleached to brightness values of $80 \%$ ISO and higher by a short ozone-based TCF sequence without any pulp pre-treatment. The ethanol-soda and organocell pulps showed the highest and practically the same brightness after complete bleaching $(83.7 \%$ and $83.4 \%$

Table 3

Properties of $\mathrm{AZE}_{\mathrm{R}} \mathrm{QP}-$ bleached organosolv and kraft (ref.) pulps from A. donax

\begin{tabular}{|c|c|c|c|c|}
\hline & \multicolumn{4}{|c|}{ Pulping process } \\
\hline & Ethanol-soda & ASAM & Organocell & Kraft (ref.) \\
\hline \multicolumn{5}{|l|}{ Bleached yield } \\
\hline ( $\%$ on oven-dry pulp) & 93.4 & 91.0 & 90.9 & 92.1 \\
\hline (\% on oven-dry reed) & 43.7 & 42.3 & 41.6 & 39.8 \\
\hline $\begin{array}{l}\text { Lignin (\% on } \\
\text { oven-dry pulp) }\end{array}$ & 1.65 & 1.89 & 1.26 & 1.66 \\
\hline Klason & 0.57 & 0.96 & 0.36 & 0.79 \\
\hline Acid-soluble & 1.08 & 0.93 & 0.90 & 0.87 \\
\hline $\begin{array}{l}\text { Intrinsic viscosity } \\
\qquad\left(\mathrm{ml} \mathrm{g}^{-1}\right)\end{array}$ & 988 & 1009 & 789 & 852 \\
\hline Brightness (\% ISO) & 83.7 & 79.4 & 83.4 & 79.6 \\
\hline Yellowness index & 7.8 & 10.1 & 8.8 & 12.5 \\
\hline Burst index $\left(\mathrm{kPa} \mathrm{m}^{2} \mathrm{~g}^{-1}\right)$ & 1.32 & 1.30 & 1.27 & 1.11 \\
\hline Tensile index $\left(\mathrm{N} \mathrm{m} \mathrm{g}^{-1}\right)$ & 15.85 & 15.28 & 14.26 & 12.38 \\
\hline Tear index $\left(\mathrm{mN} \mathrm{m}^{2} \mathrm{~g}^{-1}\right)$ & 9.16 & 9.02 & 8.54 & 8.84 \\
\hline
\end{tabular}

ISO, respectively). The final brightness of ASAM pulp was somewhat poorer and close to that of kraft pulp (79.4 and $79.6 \%$ ISO, respectively). The brightness was substantially improved in comparison with QPPP bleaching (Shatalov and Pereira, 2005) by 7.3 points (ethanol-soda pulp), 5.8 points (organocell) and 2.0 points (ASAM), while the brightness of kraft pulp was improved by 5.2 points.

The content of residual lignin (expressed as Klason and acid-soluble) in all ZEP-bleached pulps except ASAM was reduced in comparison with peroxide bleaching pointing to more intensive delignification, particularly during the ozone-stage. The removal of Klason lignin is of special importance, because of direct correlation between Klason lignin content and the kappa number commonly used in paper industry. About $83 \%$ of Klason lignin was removed during ZEP bleaching of organocell pulp, and $77 \%$ and $69 \%$ during bleaching of ethanol-soda and ASAM pulps (vs. respectively, 77\%, 68\% and 76\% after QPPP bleaching, Shatalov and Pereira, 2005). The degree of delignification of kraft pulp was close to that of ASAM and accounted for about $69 \%$ (vs. $65 \%$ for QPPP bleaching).

Reduction of ozonated pulps with a strong reducing agent during alkaline extraction stage $\left(\mathrm{E}_{\mathrm{R}}\right.$-stage enabled to limit the alkali-induced degradative reactions of carbohydrates, providing thereby the high bleached yield and pulp viscosity (Table 3), which were fairly close to those obtained after QPPP bleaching (Shatalov and Pereira, 2005). The loss in intrinsic viscosity of only $11.6 \%, 13.8 \%$ and $18.4 \%$ was found after ZEP bleaching of ASAM, ethanol-soda and organocell pulps, respectively. The degradation of kraft pulp was more intensive, with a viscosity loss of about $21 \%$.

Thus, in contrary to the expectations, the introduction of such powerful oxidation agent as ozone into the bleaching sequence did not cause any substantial harmful effect on the pulp properties in comparison with a simple multi-stage peroxide bleaching (through the undesirable side-reactions of ozone with other than lignin components), while an appreciable gain in pulp brightness and degree of delignification was achieved.

\subsection{Relative pulp bleachability and bleaching selectivity}

The change in brightness, residual lignin content and viscosity of organosolv and kraft pulps with each stage of ZEP bleaching is illustrated in Figs. 1-3.

The brightness improvement of pulps bleached under equal reaction conditions can be assumed as a measure of comparative pulp bleachability. From this standpoint, the organocell pulp showed the highest bleachability $(51.6 \%$ ISO of the overall brightness improvement after complete ZEP bleaching), followed by kraft (49.4\%), ethanol-alkali $(43.2 \%)$ and ASAM (40.5\%) pulps. The contribution of different bleaching stages (or different bleaching chemicals) to total brightness improvement varied for different pulps. The ethanol-soda pulp revealed the best bleachability by ozone, i.e., the AZ-stage bleachability (19.3\% ISO of bright- 


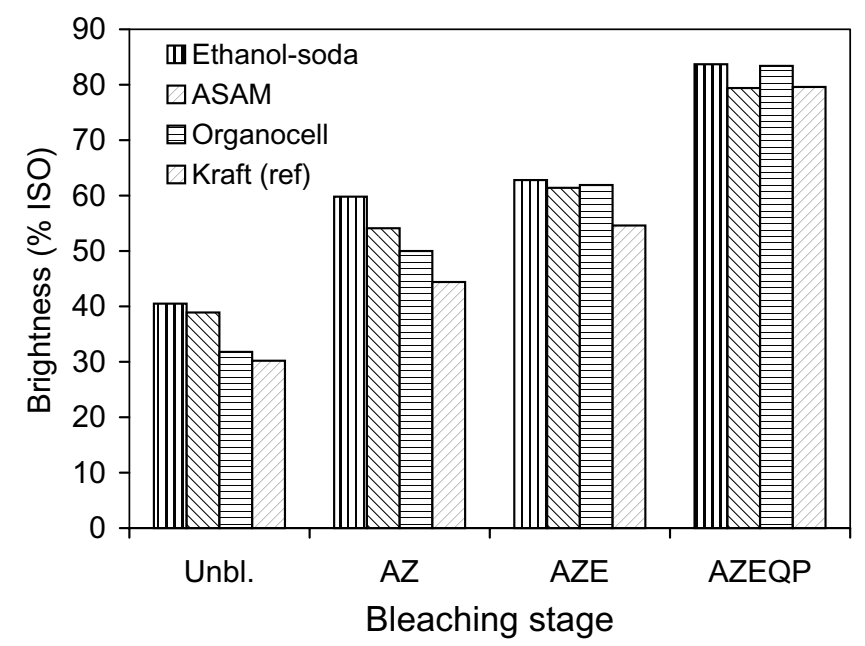

Fig. 1. Change in brightness of organosolv and kraft (ref.) giant reed pulps during each bleaching stage.

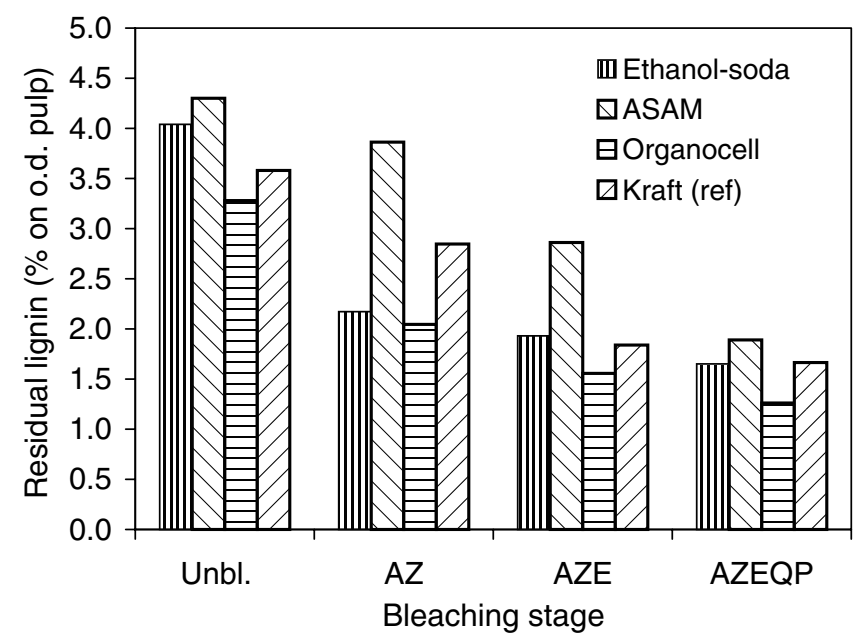

Fig. 2. Change in residual lignin content of organosolv and kraft (ref.) giant reed pulps during each bleaching stage.

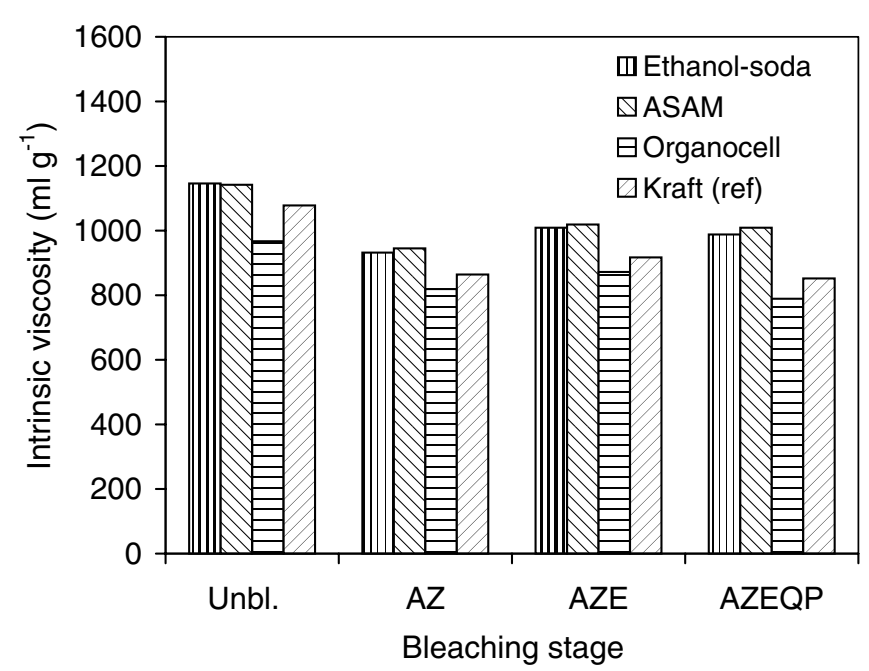

Fig. 3. Change in intrinsic viscosity of organosolv and kraft (ref.) giant reed pulps during each bleaching stage. ness improvement), followed by organocell (18.2\%), ASAM $(15.2 \%)$ and kraft $(14.2 \%)$ pulps. After alkaline extraction $\left(\mathrm{E}_{\mathrm{R}}\right.$-stage), the brightness of organocell pulp was increased somewhat more (by $11.9 \%$ ISO) than that of ASAM (7.3\%), ethanol-soda $(3.0 \%)$ and kraft $(10.2 \%)$ pulps. Finally, the hydrogen peroxide bleachability (QP-stage) of the kraft pulp was higher ( $25 \%$ ISO improvement) in comparison with organosolv pulps $(21.5 \% ; 20.9 \%$, and $18.0 \%$ for organocell, ethanol-soda and ASAM pulps, respectively).

The relative pulp bleachability can be also assessed through the efficiency in lignin removal during bleaching. The organocell pulp $(83.3 \%$ of overall lignin removed after complete ZEP bleaching) once again showed the superiority over the ethanol-soda (76.6\%), ASAM (69.5\%) and kraft $(69.1 \%)$ pulps. Similar to brightness, the effect of the different bleaching chemicals varied for the different tested pulps. The ozone was extremely effective in degradation and removal of ethanol-soda and organocell residual lignins (61.7\% and 53.0\% loss, respectively). In contrary, the delignification of ASAM pulp by ozone was very poor (about $10 \%)$ and worse than kraft (27\%). The alkaline extraction removed more lignin from ozonated kraft pulp (36.3\%), than from ASAM (28.7\%), organocell (20.0\%) and ethanolsoda $(8.8 \%)$ organosolv pulps. The hydrogen peroxide was very effective for delignification of ASAM pulp (lignin loss of $30.8 \%$ ) and had only moderate effect on organocell, ethanol-soda and kraft lignins $(10.2 \% ; 6.0 \%$ and $5.9 \%$ lignin loss, respectively).

The loss in pulp viscosity per unit of lignin removed or per unit of brightness improved during bleaching can also express the relative bleaching selectivity. It was found that the bleaching of ASAM pulp was more selective. The calculated bleaching selectivities in respect to lignin removed and brightness improved are in the ratios of 1:0.75:0.64 for ASAM, ethanol-soda and organocell pulps and 1:0.95:0.90 for ASAM, organocell and ethanol-soda pulps. The selectivity of kraft pulp bleaching was substantially poorer (respectively, 0.50 and 0.72 ).

The main drop in pulp viscosity occurs during the less selective ozone bleaching stage. The viscosity was somewhat improved after an alkaline extraction of ozonated pulps, most likely as a result of direct dissolution of low molecular polysaccharide fractions by alkaline solution and limited alkaline degradation of residual carbohydrates in the presence of reducing agent (Lindholm, 1993). The hydrogen peroxide bleaching stage had only a slight negative effect on viscosity of organosolv pulps, but affected more substantially the viscosity of kraft pulp.

\subsection{Mechanical properties of bleached pulps}

The evolution of strength properties of organosolv and kraft pulps with each bleaching stage is shown in Table 4. Generally, the bursting and tearing strength of all organosolv as well as kraft pulps after complete ZEP bleaching were close to those of unbleached pulps, while the tensile strength was significantly reduced, similar to multi-stage 
Table 4

Physical properties of $\mathrm{AZE}_{\mathrm{R}} \mathrm{QP}$-bleached unbeaten organosolv and kraft (ref.) pulps from $A$. donax

\begin{tabular}{|c|c|c|c|}
\hline $\begin{array}{l}\text { Pulping process and } \\
\text { bleaching stage }\end{array}$ & $\begin{array}{l}\text { Burst index } \\
\left(\mathrm{kPa} \mathrm{m}^{2} \mathrm{~g}^{-1}\right)\end{array}$ & $\begin{array}{l}\text { Tensile index } \\
\left(\mathrm{N} \mathrm{m} \mathrm{g} \mathrm{g}^{-1}\right)\end{array}$ & $\begin{array}{l}\text { Tear index } \\
\left(\mathrm{mN} \mathrm{m}^{2} \mathrm{~g}^{-1}\right)\end{array}$ \\
\hline Ethanol-soda $^{\mathrm{a}}$ & 1.42 & 21.51 & 9.56 \\
\hline $\mathrm{AZ}$ & 0.81 & 8.34 & 6.74 \\
\hline $\mathrm{AZE} \mathrm{R}_{\mathrm{R}}$ & 1.24 & 13.04 & 7.70 \\
\hline $\mathrm{AZE}_{\mathrm{R}} \mathrm{QP}$ & 1.32 & 15.85 & 9.16 \\
\hline ASAM $^{\mathrm{a}}$ & 1.31 & 19.20 & 8.66 \\
\hline $\mathrm{AZ}$ & 1.14 & 14.59 & 7.86 \\
\hline$A Z E_{R}$ & 1.24 & 15.10 & 8.41 \\
\hline $\mathrm{AZE}_{\mathrm{R}} \mathrm{QP}$ & 1.30 & 15.28 & 9.02 \\
\hline Organocell $^{\mathrm{a}}$ & 1.08 & 19.12 & 8.76 \\
\hline $\mathrm{AZ}$ & 0.81 & 10.02 & 7.53 \\
\hline$A Z E_{R}$ & 1.19 & 13.73 & 7.79 \\
\hline $\mathrm{AZE}_{\mathrm{R}} \mathrm{QP}$ & 1.27 & 14.26 & 8.54 \\
\hline Kraft (ref.) ${ }^{\mathrm{a}}$ & 0.96 & 15.56 & 8.22 \\
\hline $\mathrm{AZ}$ & 0.80 & 10.78 & 7.01 \\
\hline $\mathrm{AZE}_{\mathrm{R}}$ & 1.04 & 12.16 & 7.92 \\
\hline $\mathrm{AZE}_{\mathrm{R}} \mathrm{QP}$ & 1.11 & 12.38 & 8.84 \\
\hline
\end{tabular}

${ }^{\text {a }}$ Properties of unbleached pulp are given.

peroxide bleaching (Shatalov and Pereira, 2005). The ethanol-soda pulp showed the highest strength after bleaching. Similar to unbleached state, the strength properties of bleached kraft pulp were poorer in comparison with organosolv pulps.

As can be seen from Table 4, the bursting, tensile and tearing strength of all tested pulps was substantially impaired after the ozone-stage. The loss in strength is particularly notable for the ethanol-soda pulp, where the bursting strength was reduced by $43 \%$, the tensile strength by $61 \%$ and the tearing strength by $29 \%$. After subsequent alkaline extraction of ozonated pulps the strength properties were substantially improved (following to improvement of pulp viscosity), more appreciably for ethanol-soda pulp (bursting strength by $53 \%$, tensile strength by $56 \%$ and tearing strength by $14 \%$ ). The mechanical properties of all pulps were also somewhat improved with further peroxide bleaching.

As evident from Figs. 4-7, the strength properties of ozone-bleached reed pulps can be substantially developed by moderate PFI beating with minimal energy requirement. Similar to unbleached (Shatalov and Pereira, 2001) and peroxide bleached (Shatalov and Pereira, 2005) pulps, the bursting and tensile strength were greatly improved at already 500-1000 PFI revolutions. The improvement was more significant for the ASAM pulp. The maximal bursting strength of ASAM pulp $\left(9.0 \mathrm{kPam}^{2} / \mathrm{g}\right)$ was reached at 1000 PFI rev. and then decreased with beating extension, while the bursting strength of ethanol-soda and organocell pulps kept growing with beating and showed the respective maximal values of 7.7 and $6.1 \mathrm{kPa} \mathrm{m} / \mathrm{g}$ at $2000 \mathrm{PFI}$ rev. The tensile strength of ASAM pulp was sharply increased at already 500 PFI rev. and only slightly improved with further beating extension, showing a maximum value of $59.4 \mathrm{kPa}$ $\mathrm{m}^{2} / \mathrm{g}$ at 2000 PFI rev. The tensile strength of beaten organo-

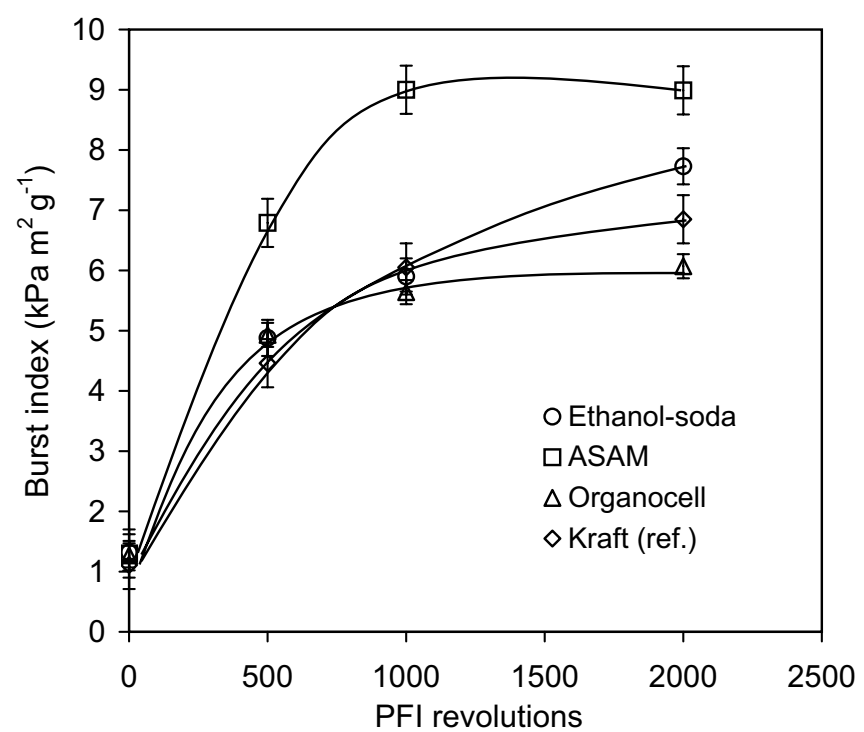

Fig. 4. Bursting strength development with PFI beating of bleached organosolv and kraft (ref.) giant reed pulps.

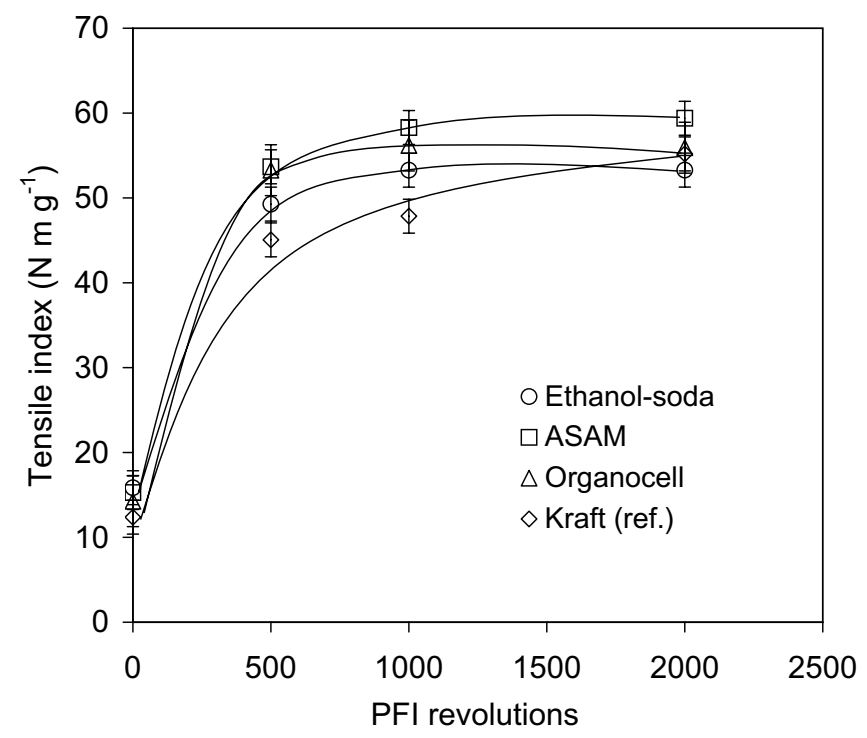

Fig. 5. Tensile strength development with PFI beating of bleached organosolv and kraft (ref.) giant reed pulps.

cell and ethanol-soda pulps followed generally the ASAM tendency, but giving somewhat lower final values (55.9 and $53.3 \mathrm{kPa} \mathrm{m}^{2} / \mathrm{g}$, respectively). The tearing strength of ozonebleached organosolv pulps was decreased with beating, as it was also noted for unbleached and peroxide-bleached giant reed pulps (Shatalov and Pereira, 2001, 2005). The loss in tearing strength was higher for ethanol-soda and organocell pulps and less for ASAM pulp (respectively, 54; 53 and $20 \%$ loss at 2000 PFI rev.). The higher response on beating of ASAM pulp is also evident from Fig. 7, where the beaten ASAM pulp showed the maximum tensile strength under the same values of tearing index.

The beating behaviour of the bleached kraft pulp was generally similar to that of organosolv pulps. The strength 


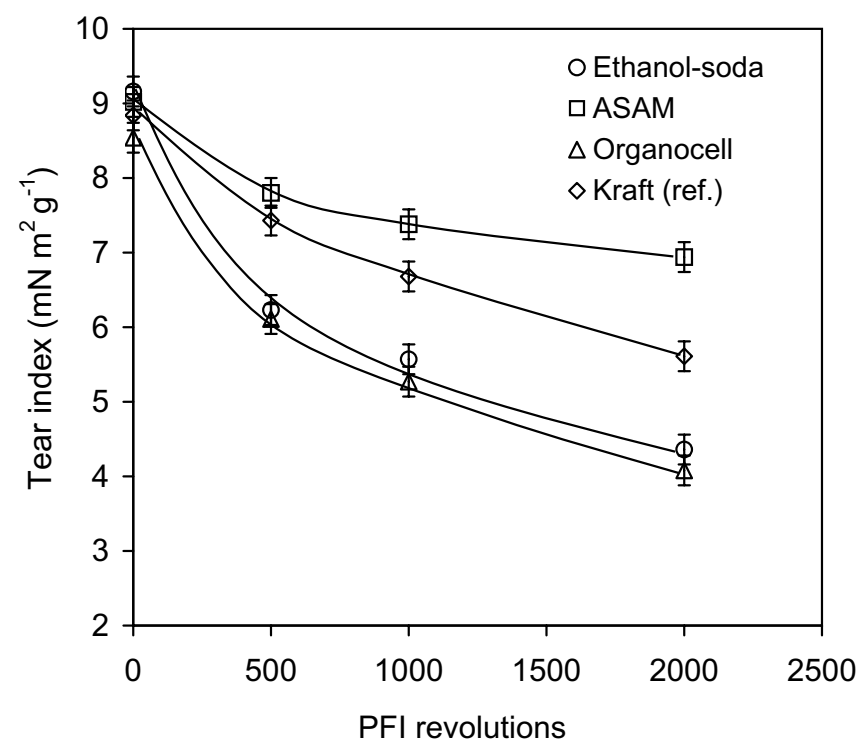

Fig. 6. Tearing strength development with PFI beating of bleached organosolv and kraft (ref.) giant reed pulps.

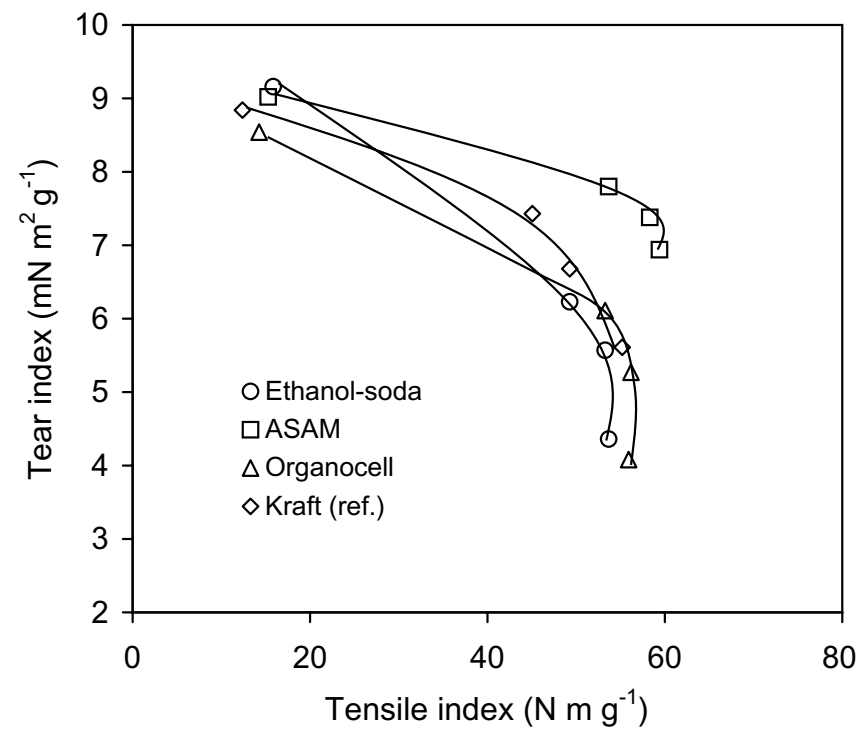

Fig. 7. Tear index vs. tensile index for beaten bleached organosolv and kraft (ref.) giant reed pulps.

properties development of kraft pulp was poorer in comparison with ASAM, but close or somewhat better (as in the case of tearing strength) to ethanol-soda and organocell pulps.

\section{Conclusions}

The ASAM, organocell and ethanol-soda organosolv pulps from giant reed can be bleached to brightness values of $80-83 \%$ ISO by a short ozone-based TCF bleaching sequence (ZEP), without any pulp pre-bleaching. The organocell pulp showed the highest bleachability, and the ASAM pulp the highest bleaching selectivity. The optical and strength properties of bleached organosolv pulps are superior to conventional kraft pulp. Pulp brightness and degree of delignification were substantially improved by the ozone bleaching in comparison with QPPP bleaching without affecting pulp strength and viscosity. In our future studies, we intend to increase the brightness ceiling of bleached reed organosolv pulps (fully bleached pulps) using various pre-treatment and activation technologies.

\section{Acknowledgements}

The financial support of Fundação para a Ciência e a Tecnologia (Portugal) within Research Contracts SFRH/ BPD/9376/2002 and POCTI/35161/AGR/2000 is gratefully acknowledged.

\section{References}

Bokstrom, M., Tuomi, A., 2001. Interest in applying ozone is growing. Paperi Ja Puu-Paper and Timber 83 (2), 124-127.

Bouchard, J., Morelli, E., Berry, R.M., 2000. Gas-phase addition of solvent to ozone bleaching of kraft pulp. J. Pulp Pap. Sci. 26 (1), 30-35.

Byrd Jr., M.V., Gratzl, J.S., Singh, R.P., 1992. Delignification and bleaching of chemical pulps with ozone: A literature review. TAPPI J. 75 (3), 207-213.

Dalianis, C.D., Sooter, Ch.A., Christou, M.G., 1994. Growth, biomass productivity and energy potential of giant reed (Arundo donax) and elephant grass (Miscanthus sinensis giganteus). In: Chartier, Ph., Beenackers, A.A.C.M., Grassi, G. (Eds.), Proceedings of the Eighth European Biomass Conference, Vienna. Pergamon, UK, pp. 575-582.

Homer, G., Muguet, M., Epiney, M., Johnson, S., 1996. Oxygen, ozone and chlorine dioxide. In: Proceedings of the Eighty-Second Annual Meeting, Tech. Sect., CPPA, Montreal, pp. A297.

King, J.E., Van Heiningen, A.R.P., 2003. Effect of pulp species and pretreatment on the rates of delignification and cellulose degradation during ozone bleaching. Pulp and Paper - Canada 104 (10), 38-42.

Kishimoto, T., Tsuji, H., Uraki, Y., Sano, Y., 2003. Ozone bleaching of atmospheric acetic acid hardwood pulp from Betula platyphylla var. japonica Hara. Holzforschung 57 (2), 181-188.

Leminen, A., Johansson, A., Lindholm, J., Gullichsen, J., Yilmaz, Y., 1996. Non-wood fibres in papermaking. VTT, Finland.

Liebergott, N., Van Lierop, B., Skothos, A., 1992a. A survey of the use of ozone in bleaching pulps, Part 1. TAPPI J. 75 (1), 145-152.

Liebergott, N., Van Lierop, B., Skothos, A., 1992b. A survey of the use of ozone in bleaching pulps, Part 2. TAPPI J. 75 (2), 117-124.

Lindholm, C.-A., 1993. Alkaline extraction of ozone-bleached pulp, Part 4. Comparison of E, (EB), (EO), (EP) and (EOP) treatment. J. Pulp Pap. Sci. 19 (3), 108-113.

Moor, G., 1996. Nonwood fibre applications in papermaking. Pira International, UK.

Munro, F., Griffiths, J., 2001. Operating experience with ozone-based ECF bleaching sequence - Results have exceeded initial expectations. Pulp and Paper - Canada 102 (9), 35-39.

Perdue, R.E., 1958. Arundo donax - source of musical reeds and industrial cellulose. Econ. Bot. 12, 368-404.

Puthson, P., Kordsachia, O., Odermatt, I., Zimmermann, M., Patt, R., 1997. ASAM pulping of Eucalyptus camaldulensisand TCF bleaching of the resulting pulps. Holzforschung 51 (3), 257-262.

Roncero, M.B., Colom, J.F., Vidal, T., 2002. Increasing the selectivity of ozone bleaching of eucalypt pulp. Part B. APPITA J. 55 (5), 386-391.

Roncero, M.B., Torres, A.L., Colom, J.F., Vidal, T., 2003. TCF bleahcing of wheat straw pulp using ozone and xylanase. Part B: Kinetic studies. Biores. Technol. 87 (3), 315-323.

Saake, B., Lehnen, R., Schmekal, E., Neubauer, A., Nimz, H.H., 1998. Bleaching of Formacell pulp from aspen wood with ozone and peracetic acid in organic solvents. Holzforschung 52 (6), 643-650. 
Shatalov, A.A., Pereira, H., 2000. Organosolv pulping of Arundo donax L. as an alternative to the kraft process for production of high quality non-wood fibres. In: Proceedings of the Sixth European Workshop on Lignocellulosics and Pulp, Bordeaux, France, pp. 571-574.

Shatalov, A.A., Pereira, H., 2001. Arundo donax L. reed: New perspectives for pulping and bleaching-2. Organosolv delignification. TAPPI J. 84 (11), 1-12.

Shatalov, A.A., Pereira, H., 2003. Influence of organosolv pulping process on TCF bleachability of Arundo donax L. pulps. In: Proceedings of the Twelfth International Symposium on Wood and Pulping Chemistry, Madison, USA, pp. 109-112.

Shatalov, A.A., Pereira, H., 2004. Arundo donax L. reed: New perspectives for pulping and bleaching-3. Ethanol-reinforced alkaline pulping. TAPPI J. 3 (2), 27-31.

Shatalov, A.A., Pereira, H., 2005. Arundo donax L. reed: New perspectives for pulping and bleaching-4. Peroxide bleaching of organosolv pulps. Biores. Technol. 96 (8), 865-872.

Shatalov, A.A., Quilhó, T., Pereira, H., 2001. Arundo donax L. reed: New perspectives for pulping and bleaching-1. Raw material characterization. TAPPI J. 84 (1), 96-107.
Van Dam, J.E.G., Van Vilsteren, G.E.T., Zomers, F.H.A., Shannon, W.B., Hamilton, I.T., 1994. Industrial fibre crops. Agro-Industrial Research Division, EC.

Van Lierop, B., Skothos, A., Liebergott, N., 1996. Ozone delignification. In: Dence, C.W., Reeve, D.W. (Eds.), Pulp Bleaching. Principles and Practice. TAPPI Press, Atlanta, pp. 321-345.

Vecchiet, M., Jodice, R., Schenone, G., 1996. Agronomic research on giant reed (Arundo donax L.) Management system and cultivation of two different provenances. In: Chartier, Ph., Ferrero, G.L., Henius, U.M., Hultberg, S., Sachau, J., Wiinblab, M. (Eds.), Biomass for Energy and the Environment. Proceedings of the Ninth European Biomass Conference, Copenhagen. Pergamon, UK, pp. 644-648.

Ververis, C., Georghiou, K., Christodoulakis, N., Santas, P., Santas, R., 2004. Fiber dimensions, lignin and cellulose content of various plant materials and their suitability for paper production. Ind. Crop Prod. 19 (3), 245-254

Zhang, X., Ni, Y., Van Heiningen, A.R.P., 1998. Basic engineering design data for ozone/solvent bleaching of ALCELL ${ }^{\circledR}$-derived pulp. Pulp and Paper - Canada 99 (1), $44-48$.

Zimmermann, M., Patt, R., Kordsachia, O., 1991. ASAM pulping of Douglas-fir followed by a chlorine-free bleaching sequence. TAPPI J., 129-134. 